\title{
Granulocytic sarcoma presented as a reactivation of chronic myeloid leukemia after allogenic marrow transplantation
}

Department of Pathology, Discipline of Hematology, Hemotherapy and Endocrinology, Escola Paulista de Medicina, Universidade Federal de São Paulo - São Paulo, Brazil

The authors report the case of a chronic myeloid leukemia (CML) patient submitted to allogenic bone marrow transplantation, who had probably never entered complete remission. The disease was reactivated as a granulocytic sarcoma, next to a platinum plate installed to correct a tibia fracture 11 years earlier. Its final event was a myeloid Ph1+ blastic crisis that was unsuccessfully treated with high doses of sc interferon and citarabine.

UNITERMS: Granulocytic sarcoma. Bone marrow transplantation. Chronic myeloid leukemia. Hypercalcemia.

\section{INTRODUCTION}

$\mathrm{G}$ ranulocytic sarcoma (GS) is an extramedullary tumor originally called chloroma ${ }^{(1)}$ due to its green-colored aspect. It is frequently reported in young patients with acute myeloid leukemia (AML) and chronic myeloid leukemia (CML). It mainly involves the periosteum of skull bones, sternum, vertebrae, and less frequently the soft tissues of the chest wall, arms, skin, kidney, gut, ovary, lung and lymph nodes ${ }^{(1)}$. Its pathogenesis is unknown, although there is a hypothesis that traumatic extravasation and proliferation of mitotically competent leukemic cells in normal tissues could explain

\author{
Address to correspondence: \\ José Salvador R. de Oliveira \\ Rua Botucatu, 740 - 3o. andar - Hematologia \\ São Paulo/SP - Brasil - CEP 04023-900 \\ e-mail: unifesp@epm.br
}

its appearance ${ }^{(1)}$. Isolated GS seems to be a rare disease, particularly after marrow transplantation. After review, we found only one previous report of cutaneous GS after autologous bone marrow transplantation for acute myeloid leukemia $(\mathrm{AML})^{(1)}$.

\section{CASE REPORT}

A 26 year-old female patient was diagnosed as having Ph1+ CML in 1992, which was successfully controlled with hydroxyurea. She had a history of a surgery in the left tibia after an accident 11 years earlier.

In August 1993, she was treated with bussulfan and cyclophosphamide as a conditioning regimen to kill her normal and malignant CML clones, and received bone marrow cells from her brother, an identical HLA donor (locus A,B and DR). Graft versus host disease (GVHD) 
prophylaxis was necessary to avoid a reaction of the donor's immune system against host tissues (such as skin, gut, liver) and, in this case, it consisted of cyclosporin plus short term methotrexate. Prophylaxis of cytomegalovirus infection was performed using acyclovir until engraftment and thereafter with gancyclovir. As a complement for infection and GVHD prophylaxis, IV immunoglobulin was used from day -6 to day +100 . During the neutropenic period, she received a 21-day imipenem course. GM-CSF was used to stimulate bone marrow engraftment from day +1 to +18 , when the granulocyte count reached $1500 / \mathrm{mm}^{3}$.

On day +220 post transplantation, and exactly 10 days after the end of immunosuppression, swelling and erythema were observed in the left knee simultaneously with local pain and immobilization. Several synovial fluid aspirations showed low lymphocyte counts and sterile cultures. Local X-ray, ultrasonography, double phase Tcscintillography and magnetic resonance images were suggestive of distal femur osteomyelitis. She was treated with vancomycin for 35 days without success. At that time the $\mathrm{Ph} 1$ chromosome was present in less than $10 \%$ of the analyzed cells, and also bcr-abl rearrangement was positive by RT-PCR, showing persistence of minimal residual disease but not necessarily MT failure (Fig. 1).

At day +276 she complained of pain and enlargement of the left knee. She was submitted to a synovial biopsy

$\% \operatorname{Ph} 1$

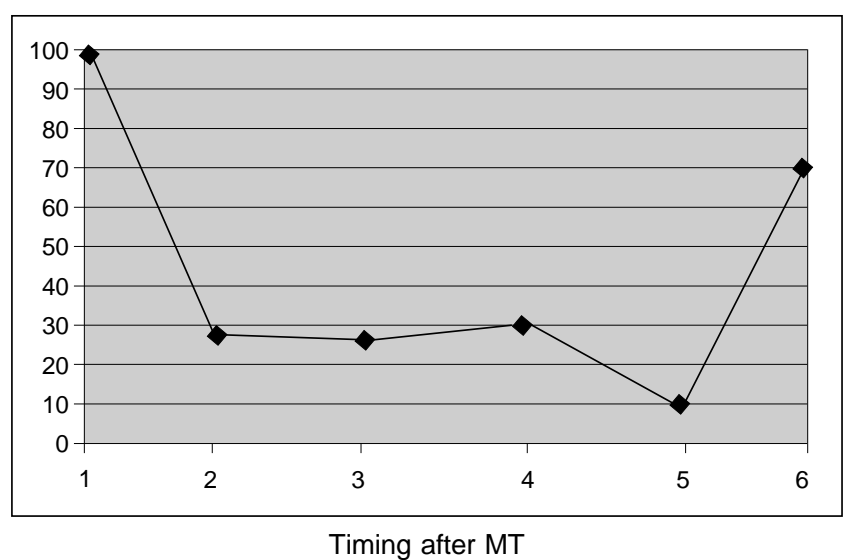

1. a month before $\mathrm{MT}$ - $46, \mathrm{XX}, \mathrm{t}(9 ; 22) 100 \%$.

2. day $+21,46, X Y 71.5 \%, 46, X X, t(9 ; 22) 28.5 \%$.

3. day +68 , sustained engraftment - $46, X Y 75 \%, 46, X X, t(9 ; 22) 25 \%$. 4. day +98 , sustained engraftment- $46, X Y 65 \%, 46, X X 5 \%$ e $46, X X$, $t(9 ; 22) 30 \%$

5. day +214 , clinical evidence of GS - 46, XY 89.5\%e 46, XX, t(9;22) $10.5 \%$ 6. day +473 , AML episode - 46, XY $31.5 \%$ e 46, XX, t $(9 ; 22) 68.5 \%$.

Figure 1 - Ph1 chromosome evolution in bone marrow samples after MT. which was suggestive of granulocytic sarcoma. Immunohistochemical reactions were positive for lysozyme and $\mathrm{CD} 45$ and negative for $\mathrm{B}$ and $\mathrm{T}$ antigens, confirming the diagnosis of GS (Fig. 2). At this time, Tc-bone scintillography scanning of the skeleton was normal. She received irradiation of $5000 \mathrm{cGy}$ on her left knee and was maintained under observation for 5 months, until the onset of a $1.5 \mathrm{~cm}$ node in her right breast and a large tumor in the right iliac bone. The biopsies of both lesions showed the same morphology and reactions previously described. Fifteen months post marrow transplantation, $\mathrm{Ph} 1+$ acute myeloid leukemia was fully developed. She was treated with alpha interferon and citarabine, and peripheral blast cell count and tumoral mass decreased within 25 days. As a complication of multiple bone GS, she evolved to hypercalcemia (calcium level: $1.79 \mathrm{mMol} / 1$; PTH level: 9pg/ $\mathrm{ml}$ ), which was treated with vigorous hydration, prednisone and pamidronate. Thirty five days after the diagnosis of acute leukemia, she died due to a sudden febrile interstitial pneumonia. Marrow and WBC counts were compatible with hypoplasia post- chemotherapy. Post mortem examination was not allowed by her relatives.

\section{DISCUSSION}

CML is a malignant disease with a fatal outcome after a blast crisis within approximately three years. HLA related bone marrow transplantation represents the only chance of cure for patients younger than 40 years old, especially if performed during the first year after the diagnosis ${ }^{(2)}$. Thus, bone marrow transplantation was indicated for our patient.

Light to moderate GVHD is a desirable effect in marrow transplantation to avoid clinical, cytogenetic and even molecular relapse. Disease control is the result of an interaction between donor immune system cells and the host CML clone ${ }^{(3)}$. Several observations have demonstrated higher relapse rates in syngenic transplantations and in $\mathrm{T}$ cell depleted allografts. Patients with acute and chronic GVHD have a lower relapse rate compared to individuals that do not suffer from this complication, and finally, relapsed patients can be successfully treated with leukocyte infusions obtained by cytopheresis from the original donor. In the present case, the long period of IV immunoglobulin infusion to prevent infections and $\mathrm{GVHD}^{(4,5)}$ resulted in no evidence of GVHD, which probably contributed to the absence of the desirable graft-versus-leukemia effect. Therefore, IV immunoglobulin is preferentially indicated 
when some grade of GVHD is expected, particularly for unrelated donors and non-identical siblings.

The rare event described here was difficult to identify by conventional image methods and only the open biopsy led to the correct diagnosis. The patient had molecular evidence of minimal residual disease when the inflammatory process started and the $\mathrm{Ph} 1$ clone could be detected by a cytogenetic relapse later.

In the present case, GS appeared as a late complication of marrow transplantation next to a platinum plate installed after trauma many years earlier. We believe that there was some grade of traumatic fibrosis next to the plate which led to inadequate blood supply for chemotherapy in this area. So, an unanswered question remained: could the previous status of the proximal tibia and knee have been a barrier against the destruction of leukemic cells at these sites?

Unfortunately, she was not in a clinical condition to be submitted to a second MT, but leukopheresis from the donor's marrow could have been a good alternative procedure at that time. The option of treatment with interferon after the AML event was based on some evidence of clinical improvement under such a regimen in CML patients who relapsed after $\mathrm{MT}^{(3)}$.

About 30 cases of hypercalcemia associated with CML have already been documented ${ }^{(6)}$. As was observed in the present case, hypercalcemia signifies bad prognosis. The pathogenesis of hypercalcemia in CML is still unclear, but generally it is attributed to bone invasion and destruction by leukemic cells. Standard therapy for hypercalcemia (hydration followed by forced diuresis, corticosteroids or calcitonin) may be not successful. It is reported that effective treatment requires administration of pamidronate, which promotes a relatively selective inhibition of osteoclast activity or chemotherapy directed to leukemia ${ }^{(6)}$, as we could observe in this case.

We suggest that many factors such as 1) the absence of any manifestation of chronic GVHD, 2) the use of high and extended IV immunoglobulin doses, 3) post traumatic tibia fibrosis and 4) the persistence of CML clones after marrow transplantation could have contributed to the outbreak of GS and further AML. Unfortunately, as demonstrated by her clinical course, the CML clones had never been eradicated by the marrow transplantation.

\section{Resumo}

Os autores relatam um caso de leucemia mielóide crônica tratada com transplante alogênico de medula óssea e que provavelmente nunca entrou em remissão completa da doença. A paciente apresentou reativação como sarcoma granulocítico junto a uma placa de platina instalada há 11 anos, após fratura de tíbia. Descrevem também outras manifestações de recidiva e término em crise blástica mielóide Ph1+ sem sucesso tratada com altas doses de interferon se e citarabina.

\section{REFERENCES}

1. Harris DWS, Osterele LS, Rustin MHA. Cutaneous granulocytic sarcoma (chloroma) presenting as the first sign of relapse following autologous bone marrow transplantation for acute myeloid leukemia. Br J Haematol 1992; 127:182-184.

2. Champlin RE, Golde DW. Chronic myelogenous leukemia: recent advances. Blood 1985; 65:1039-1047.

3. Clift RA, Buckner CD, Thomas ED, et al. Marrow transplantation for chronic myeloid leukemia: a randomized study comparing cyclophosphamide and total body irradiation with bussulfan and cyclophosphamide. Blood 1994; 84:203643.
4. Sullivan KM, Kopercky KJ, Jocom J, et al. Immunomodulatory and antimicrobial efficacy of intravenous immunoglobulin in bone marrow transplantation. N Engl J Med 1990; 323:705-712.

5. Sullivan KM, Storek J, Kopecky KJ, et al. A controlled trial of long-term administration of IV immunoglobulin to prevent late infection and chronic GVHD after marrow transplantation: clinical outcome and effect of subsequent immune recovery. Biology of Blood and Marrow Transplantation. 1996; 2:44-53.

6. Kubota K, Yanagisawa T, Kurubayashi H, et al. Hypercalcemia associated with osteolytic lesions in extramedullary blastic crisis of chronic myelogenous leukemia: report of a case. Blut 1989; 59:458-459. 